＜原＼cjkstart著＞

肝細胞の極性形成に怙けるデスモンームと 中間径フィラメントの役割

$\begin{array}{llllll}\text { 森本 } & \text { 道雄 } & \text { 岡上 } & \text { 武 } & \text { 君藤 } & \text { 義人 } \\ \text { 太田 } & \text { 正治 } & \text { 太田 } & \text { 義治 } & \text { 岡 } & \text { 正直 } \\ \text { 長尾 } & \text { 泰孝 } & \text { 香川 } & \text { 恵造 } & \text { 加嶋 } & \text { 敬* }\end{array}$

要 旨: コラゲナーゼ灌流法で肝細胞を単離, 培養開始後, 経時的にサイトケラチン (CK) と デスモプラキン（DP）の存在様式を蛍光抗体法で観察した。また, detergent 処理した非包埋 試料を用い, 免疫電顕による検討も行った。単離直後,肝細胞は球形で個々ばらばらに存在し, 培着12時間後までは毛細胆管の形成, DP の局在はともに明らかでなかった。培養24時間後, 肝 細胞は隣接する細胞間で広い範囲で接着し，CK の染色では毛細胆管と考えられる管腔を形成 していた。この時, 細胞間, 毛細胆管周囲にはDP の虽光を明暸に認めた。免疫電顕に上る検討 で，中間径フィラメント（IF）が肝細胞内に微細なネットワークを形成し，毛細胆管を支持す る裏打ち構造す存在し, DP を標識する金粒子が細胞間接合部, 毛細胆管周囲の IF 上に多数存 在していた，今回の研究から肝細胞の極性形成に IF に関連してデスモンームが重要な役割を 担っていることが明らかになった。

来引用語： 培養肝細胞 極性 デスモソーム 中間径フィラメント

\section{緒 言}

初代培養肝細胞は適切な条件下で隣接する細胞との 間に毛紐胆管と考えられる管空を形成する ${ }^{1.2)}$. 肝細胞 は一定の極性を持ち，この極性のるとで種々の機能を 発揮しているむのと考えられ，この意味で肝細胞の極 性形成の研究は興味あるテーマである。培養肝細胞に おける毛細胆管再構築は極性研究の絶好の研究モデル と思われる。近年, in vivo 毛細胆管周囲には中間径 フィラメント (IF) で構成される pericanalicular sheath (PS) と呼ばれる構造物が存在すると報告され ている ${ }^{3)}$. in situ 毛細胆管のこの構造的特徵から IFや 細胞間接着装置であるデスモンーム (DS) は細胞の極 性出現に重要な役割を担っていると考えられる.今回， 我々は単離肝細胞培盖系で，毛細胆管再構築に焦点を あて，IF と DS を経時的に観察したので報告する。

対象と方法

体重約 $200 \mathrm{~g}$ のWistar 采雄性 ラット5 5 匹を用い。 $0.05 \%$ コラダナーゼ灌流法で肝細胞を分離, $50 \times \mathrm{g}$ の

*京都府立医科大学第 3 内科

〈受付日1990年 4 月25日＞
低速遠沈と直径 $30 \mu \mathrm{m}$ のナイロンメッシュによる滤過 にて肝細胞を精製した。培地は，10\%胎児牛血清 (Hyclone) を含むDulbecco's modified minimum essential medium of Eagle (D-MEM) k, インスリ ソ10-7 M, デキサメサゾン10-7 M を添加して使用した。 単離肝細胞を培盖液中に分散し, $5 \times 10^{5}$ 個 $/ \mathrm{ml}$ の樒度 に調整後, $35 \mathrm{~mm}$ ディッシニに $2 \mathrm{ml}$ ずつ播種, $5 \% \mathrm{CO}_{2}$

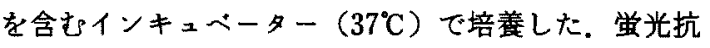
体法には，タイプIコラーゲン (Cell Matrix：新田ゼ ラチン)をコートしたガーーグラス上で培盖し, $-20^{\circ} \mathrm{C}$ 冷アセントで10分間固定の後, phosphate buffer saline (PBS) (pH7.4) で洗浄し，一次抗体としてマ ウス IgG 抗サイトケラチン (CK)モノクローナル抗体 (PKK1： Labsystems, Helsinki, Finland) あるいは 抗デスモブラキン (DP) モノクローナル抗体（DP1＆ 2, Boehringer Mannheim) と室温で 1 時間インキュ ベートした, PBSで洗浄後, FITC 標識ヤギ抗マウス IgG 抗体 (Cappel, West Chester) とさらに 1 時間反 応させ，洗浄・包埋後，虽光顕微鏡で観察した。

免度電影法は，コラーゲンコートしたフォルムバー ルを張った金グリッド上で培養し, Fey \& Penman 
の方法4を改良したKatsumaらの方法"゙に従い, Triton X-100, DNase, RNase 含有液で処理し, 抗 DP 抗体之 1 時間反応後, 直径 $10 \mathrm{~nm}$ の金粒子標識二次抗 体 Auro Probe EM GAM IgG G10 (Janssen Life Science Products, Olen, Belguim）と室温で 1 時間反 応させ, PBS で洗浄後, $2.5 \%$ クタルアルデヒドで30 分間固定した。 エタノール系列で脱水し, 臨界点乾燥 後カーボン蒸着し, 日立 $\mathrm{H}-500 \mathrm{H}$ 透過型電顕で観察し た.

\section{結果}

単離直後には肝細胞は 1 個 1 個分離して存在し, 培 養 6 時間後では，球形の肝細胞が $2 \sim 10$ 個集団をなし

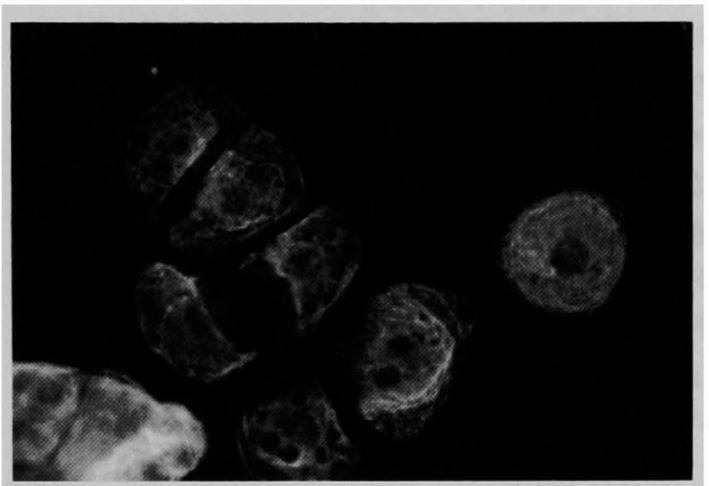

Fig. 1 Immunofluorescence of hepatocytes stained with anti-cytokeratin monoclonal antibody after post-seeding $6 \mathrm{hrs}$. They aggregate forming small groups composed of a few hepatocytes. $\times 360$.

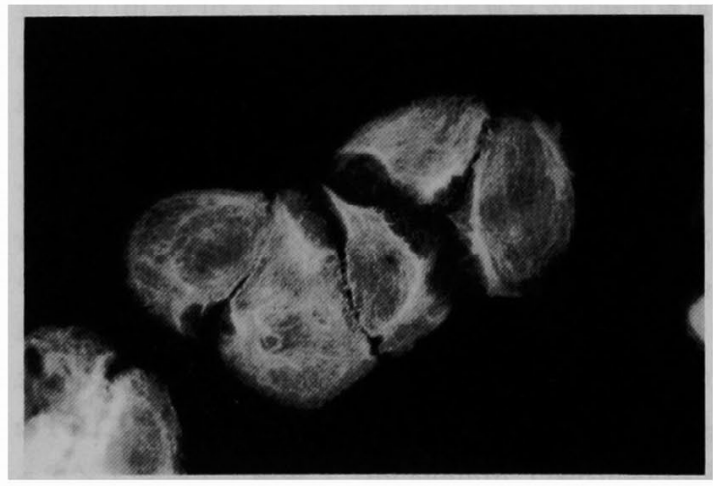

Fig. 2 Immunofluorescence of hepatocytes stained with anti-cytokeratin monoclonal antibody after post-seeding $12 \mathrm{hrs}$. They form wide contacts with neighboring cells. Cytokeratin filaments show a meshwork throughout the cytoplasm. $\times 360$.
ていた（Fig. 1)，培養12時間後，CK は細胞内に網目 状に観察されたが（Fig. 2)，DPを示す蛍光に局在は なく不明暸であった (Fig. 3)。培養24時間後には，肝 細胞は培地に接着・伸展し多角形を呈し, 隣接する細 胞間で広い範囲で接着していた，CKは細胞質全体に 網目状に認め, 細胞間で一部管腔様構造を形成してい た（Fig. 4)，DP は主に細胞間に点状に並んで観察さ れ(Fig. 5), detergent 処理後, 虽光は明暸となり毛細 胆管周聿にも明らかに観察された(Fig. 6). 電影では, 培養24時間後，肝細胞 IF は細胞内で钽細なフィラメ ントネットワークを形成し, 特に細胞接合部に密に存 在していた (Fig. 7)。 また，細胞境界部には，毛細胆

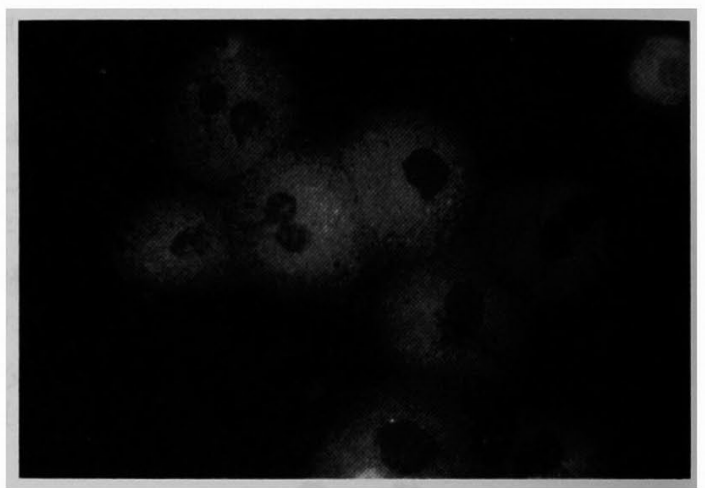

Fig. 3 Immunofluorescence of hepatocytes stained with anti-desmoplakin monoclonal antibody at the same time of Fig. 2. Fluorescence labeling desmoplakin is obscure. $\times 360$.

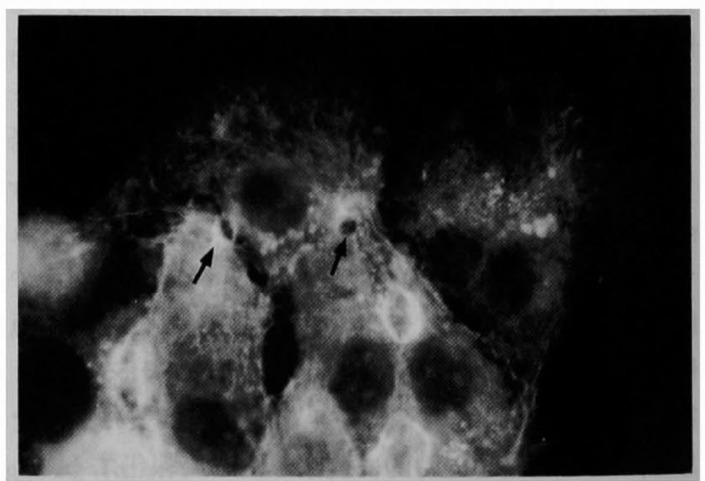

Fig. 4 Immunofluorescence micrograph of hepatocytes for $24 \mathrm{hrs}$ incubation stained with anti-cytokeratin monoclonal antibody. Cytokeratin networks in the cytoplasm are noted and pericanalicular sheath is formed with a contiguous hepatocyte, which might correspond to bile canaliculus. (arrowhead: bile canaliculus) $\times 570$. 


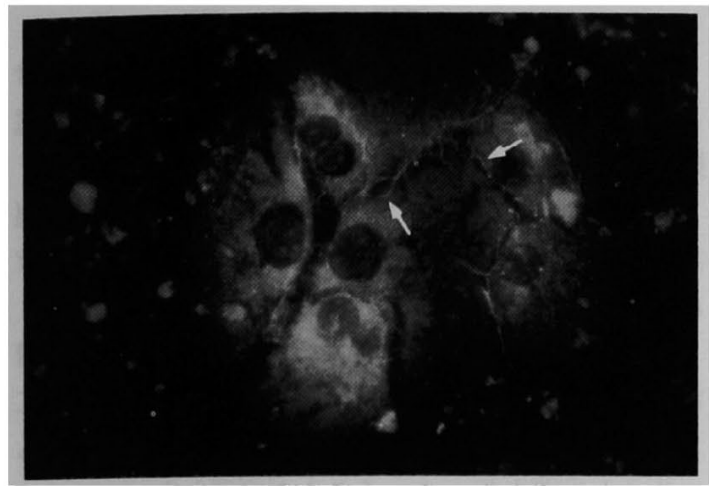

Fig. 5 Immunofluorescence of hepatocytes stained with anti-desmoplakin monoclonal antibody at the same time of Fig. 4. Desmoplakin is observed at the cell-cell contacts and around bile canaliculi as seen in the dotted lines. (arrow. head: bile canaliculus) $\times 360$.

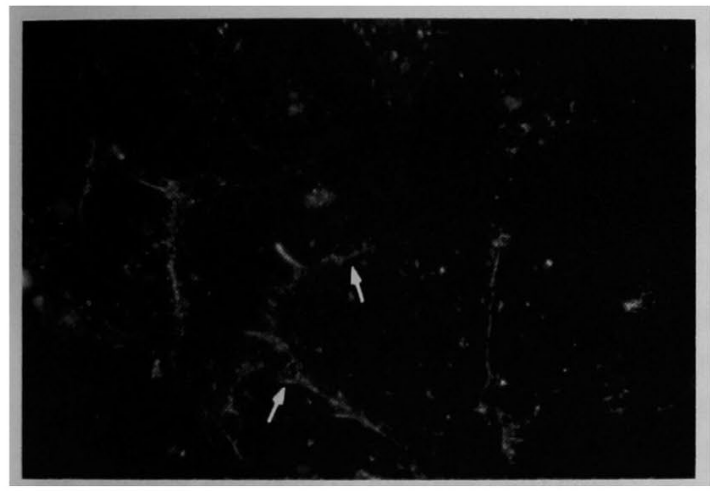

Fig. 6 Immunofluorescence of detergent-treated hepatocytes stained with anti-desmoplak in monoclonal antibody. Compared with the non detergent-treated specimen (Fig. 5) the fluorescence of desmoplakin is more clearly observed. (arrowhead: bile canaliculus) $\times 420$.

管に対応する管腔が観察され(Fig. 8), 免度電顕では, その部位に DP を標識する多数の金粒子が存在してい た.

\section{考 察}

肝細胞、消化管上皮などの上皮細胞は極性を持って 種々の機能を発揮していることが特徵であり，その極 性の形成には細胞骨格が大きな役割を果たしていると 考えられている、サイトヶラチンはIF を構成する蛋 白であり。一部の例外を除き5.6) 上皮細胞固有の蛋白之 考えられている7,8)。肝細胞には類洞側，毛細胆管側の

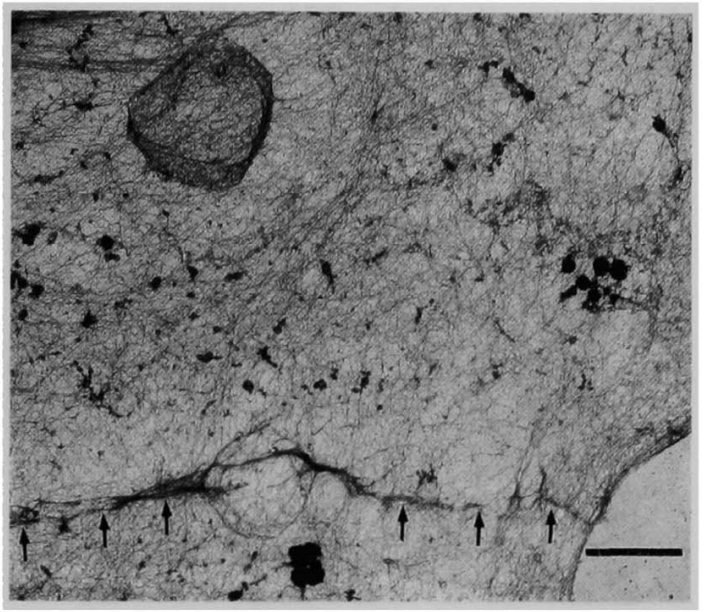

Fig. 7 Transmission electron micrograph of the whole mount unembedded extracted hepatocytes after post-seeding $24 \mathrm{hrs}$. Intermediate filaments show a fine network throughout the cytoplasm. Bar measures $4 \mu \mathrm{m}$.

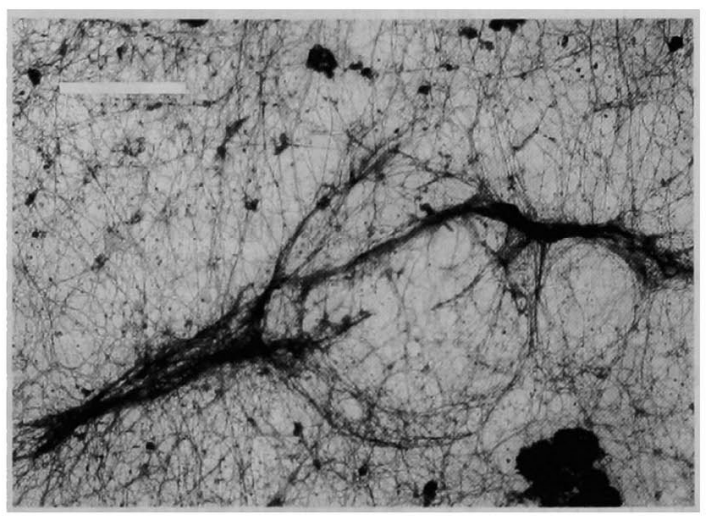

Fig. 8 A higher magnification of Fig. 7. The lining structure of IFs is clearly seen around the bile canaliculus. Bar measures $2 \mu \mathrm{m}$.

よらな極性があり、ゴルシ体や粗面小胞体が毛細胆管 側に近く存在している。毛細胆管は隣合ら肝細胞間に 存在し，乙の形成には細胞同士の協調が大切であり， 細胞間の情報伝達機構の存在が想定される。 また, 通 常電顕による研究では, 肝細胞毛細胆管周囲には, 管 腔側より, zonula occludens(tight junction), zonula adhaerens (intermediary junction), macula adhaerens (desmosome) という順に junctional complex を 形成していることが知られている1,9.10)。デスモンーム という細胞間接着装置は上皮細胞に広く存在し9”, そ 


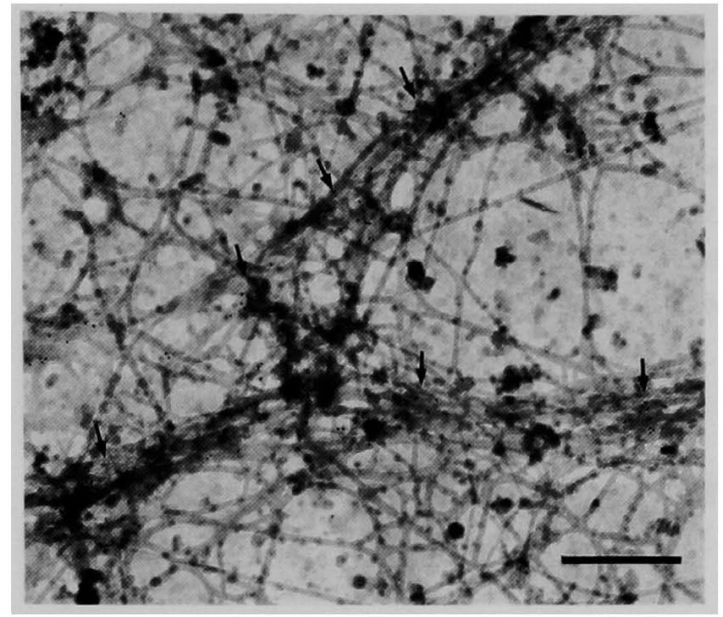

Fig. 9 Immunoelectron micrograph of the whole mount unembedded extracted hepatocytes after post-seeding 24 hrs. A large number of gold particles labeling the desmosomes (arrows) are densely noted at the cell border and around the bile canaliculus. Bar measures $0.5 \mu \mathrm{m}$.

の構成蛋白であるデスモプラキンは表皮, 汗腺, 消化 管上皮，子宮など種々の上皮細胞に分布し，ヒト，ラッ トを問わず共通の抗原性を有している ソームには IF が付着し，IFは細胞内に網の目ように 張り巡らされ7, 細胞内小器官の空間配置に関与して いると考えられている. 近年, Katsuma らは detergent 処理した肝組織の観察から, in situ 毛細胆管周囲 にはIFにより形成されるPSと呼ばれる構造物が存 在し，デスモンームがその上に並んで存在していると 報告している3!。充た，単離肝細胞は適切な条件下で毛 細胆管を再構築するが'1,2)，これは細胞の極性を研究す る上で絶好のモデルと考学られる。したがって，デス モソームの出現と細胞の極性出現には密接な関連性が あるものと想定される。

今回著者らは，単離肝細胞の培養系で毛細胆管の再 構築時におけるIFとデスモンームの関係を経時的に 観察し、デスモプラキンの存在と毛細胆管の再構築と が密接に関係していることを示した，そして，デスモ ブラキンの出現時には肝細胞 IF は毛細胆管周囲に籠 状の構造物を形成し, IF は細胞内に網目状に分布して いることを透過電顕で明暸に描出した，肝細胞の極性 出現にはデスモンームの形成が重要であり,今後, 細 胞の極性の研究を進める上でデスモソーム, IF の動態 の解析は重要と思われた。
結語

初代培養肝細胞を用いて，肝細胞の極性形成におけ る IF とデスモンームとの関係を蛍光抗体法，免疫電 顕で検討し以下の結論を得た。

1）毛細胆管形成時には in situ と同様，IF による亭 打ち構造(PS)が存在し，その集合した IF の結合部位 にはデスモソームが形成されていた。

2）経時的な観察より,デスモプラキンの細胞間接着 部への出現と毛細胆管の再構築は密接な関係を有して おり，デスモンームは肝細胞の極性形成に IF ととも に大きな役割を担っていることが判明した。

本論文の要旨は, 第31回日本消化器病学会大会において 発表した。

\section{文献}

1) Wanson JC, Drochmans P, Mosselmans R, et al: Adult rat hepatocytes in primary monolayer culture : Ultrastructural characteristics of intercellular contacts and cell membrane differentiations. J Cell Biol 74 : 858-877, 1977

2) Penasse W, Bernaert D, Mosselmans R, et al : Scanning electron microscopy of adult rat hepatocytes in situ, after isolation of pure fractions by elutriation and after culture. Biol Cell $34: 175-186,1979$

3) Katsuma $Y$, Marceau N, Ohta M, et al : Cytokeratin intermediate filament of rat hepatocytes: different cytoskeletal domains and their three dimensional structure. Hepatoloy 8 : 559-568, 1988

4) Fey E, Won KM, Penman S: Epithelial cytoskeletal framework and nuclear matrix intermediate filament scaffold: Three dimensional organization and protein composition. J Cell Biol 98 : 1973-1984, 1984

5) Kuruc N, Franke WW : Transient coexpression of desmin and cytokeratins 8 and 18 in developing myocardial cells of some vertebrate species. Differentiation 38: 177-193, 1988

6) Muijen GNPV, Ruiter DJ, Warnaar SO: Coexpression of intermediate filament polypeptides in human fetal and adult tissues. Lab Invest 57 : $359-369,1987$

7) Lazarides E: Intermediate filaments as mechanical integrators of cellular space. 
Nature $283: 249-256,1980$

8) Sun TT, Shik C, Green H: Keratin cytoskeletons in epithelial cells of internal organs. Proc Natl Acad Sci USA 76: 2813-2817, 1979

9) Farquhar MG, Palade GE: Junctional complexes in various epithelia. J Cell Biol $17: 375$ $-412,1963$

10) Goodenough DA, Revel JP: A fine structural analysis of intercellular junctions in the mouse liver. J Cell Biol 45: 272-290, 1970

11) Franke WW, Schmid E, Grund C, et al : Antibodies to high molecular weight polypeptides of desmosomes: Specific localization of a class of junctional proteins in cells and tissues. Differentiation $20: 217-241,1981$
12) Cowin P, Garrod DR: Antibodies to epithelial desmosomes show wide tissue and species cross-reactivity. Nature $302: 148-150,1983$

13) Cowin P, Mattey D, Garrod D: Distribution of desmosomal components in the tissues of vertebrates, studied by fluorescent antibody staining. J Cell Sci 66 : 119-132, 1984

14) Osborn $M$, Weber $K$ : A monoclonal antibody recognizing desmosomes: Use in human pathology. J Invest Dermatol 85 : 385--388, 1985

15) Muller H, Franke WW: Biological and immunological characterization of desmoplakins I and II, the major polypeptides of the desmosomal plaque. J Mol Biol $163: 647-671,1983$

\title{
Role of intermediate filaments and desmosome in the formation of polarity of hepatocytes
}

\author{
Michio Morimoto, Takeshi OKanoue, Yoshito Itoh, Masaharu OHTA, \\ Yoshiharu OHTA, Masanao OKA, Yasutaka NAGAO, \\ Keizo Kagawa and Kei KashIMA*
}

Isolated rat hepatocytes were obtained by perfusion method and purified by centrifugation and filtration. Immunofluorescence microscopy and immunoelectron microscopy (IEM) were applied to observe the relationship between intermediate filaments (IFs) and desmosomes (DSs) in the non detergent-treated and the detergent-treated hepatocytes using monoclonal antibodies to cytokeratin (CK) and desmoplakin (DP). Immediately after seeding hepatocytes were showed in round shape and divided into single cells. Untill $12 \mathrm{hrs}$ later bile canaliculi and DP were not clearly observed. $24 \mathrm{hrs}$ later hepatocytes attached to the dish and spread in a polygonal shape showing straight contacts with contiguous cells. CK filament networks formed cavities intercellularly and DP was observed at the cell borders and around $\mathrm{BC}$ in dotted lines. IEM revealed that IFs forming a filamentous network were densely noted at the cell borders and around the cavities where a large number of gold particles labeling DP were seen. Our results indicate that DS associated with IFs plays an important role in the formation of polarity of hepatocytes including the formation of PS.

\footnotetext{
* Third Department of Internal Medicine, Kyoto Prefectural University of Medicine (Kyoto)
} 